\title{
Dopamine Induces a PI3-Kinase-Independent Activation of Akt in Striatal Neurons: A New Route to cAMP Response Element-Binding Protein Phosphorylation
}

\author{
Karen Brami-Cherrier, ${ }^{1}$ Emmanuel Valjent, ${ }^{1}$ Marta Garcia, ${ }^{1}$ Christiane Pagès, ${ }^{1}$ Robert A. Hipskind, ${ }^{2}$ and \\ Jocelyne Caboche ${ }^{1}$ \\ ${ }^{1}$ Laboratoire de Neurobiologie des Processus Adaptatifs, Centre National de la Recherche Scientifique/Université Pierre \\ et Marie Curie, Unité Mixte de Recherche 7102, 75005 Paris, France, and 2Institut de Génétique Moléculaire, Unité Mixte \\ de Recherche 5535, Centre National de la Recherche Scientifique, 34293 Montpellier, France
}

\begin{abstract}
Akt is classically described as a prosurvival serine/threonine kinase activated in response to trophic factors. After activation by phosphoinositide 3-kinase (PI3-kinase), it can translocate to the nucleus where it promotes specific genetic programs by catalyzing phosphorylation of transcription factors. We report here that both dopamine (DA) D1 (SKF38393) and D2 (quinpirole) agonist treatments rapidly increase, in primary striatal neurons in culture, phosphorylation levels of Akt on $\mathrm{Thr}^{308}$, a residue that is critically involved in its kinase activity. These treatments also activate the extracellular signal-regulated kinase (ERK) pathway in the same population of striatal neurons. Induction of active, phospho-Thr ${ }^{308}$ Akt by dopamine D1 and D2 agonists is insensitive to wortmannin and thus PI3-kinase independent, in contrast to growth factor-induced Akt activity. D1- and D2-induced phospho-Thr ${ }^{308}$ Akt is decreased by the mitogen-activated protein kinase kinase (MEK) inhibitor, U0126,
\end{abstract}

Originally characterized on the basis of its sequence homology with the v-akt oncogene and with protein kinase A (PKA) (Bellacosa et al., 1991; Coffer and Woodgett, 1991; Jones et al., 1991), the protein kinase $\mathrm{B}(\mathrm{PKB}) / \mathrm{Akt}$ is an important mediator of the physiological effects of several growth and survival factors; notably, it promotes cell survival through the inhibition of apoptosis (for review, see Downward, 1998; Datta et al., 1999). Akt is a member of the serine/threonine kinase family (Alessi et al., 1997) and is a major target, via its pleckstrin homology $(\mathrm{PH})$ domain, of the phosphoinositide 3-kinase (PI3-kinase) (Burgering and Coffer, 1995; Franke et al., 1995). During growth factor stimulation, PI3-kinase increases levels of the lipid second messenger, phosphatidylinositol 3,4,5-triphosphate (PI-3,4,5P3) (Hemmings, 1997; To-

\footnotetext{
Received June 3, 2002; revised July 23, 2002; accepted July 26, 2002.

This work was supported by the Université Pierre et Marie Curie (UPMC), the Centre National de la Recherche Scientifique (CNRS), the Ministère de la Recherche (Action Contertée Incitative Développement et Physiologie Intégrative), and the Association pour la Recherche sur le Cancer (contract 5618 to J.C. and 5890 to R.A.H.). K. Brami-Cherrier was supported by the CNRS and Fondation Lejeune. E. Valjent was supported by a grant from "Fondation pour la Recherche Médicale." We thank Dr. Dario Alessi for the generous gift of DN-Akt plasmid, Dr. Marie Körner for technical help, and Richard Schwartzmann for confocal analysis.

Correspondence should be addressed to Jocelyne Caboche, Laboratoire de Neurobiologie des Processus Adaptatifs, Centre National de la Recherche Scientifique/ UPMC, Unité Mixte de Recherche 7102, 9 quai Saint Bernard, 75005 Paris, France. E-mail: Jocelyne.Caboche@snv.jussieu.fr.

E. Valjent's present address: Laboratoire Transduction du Signal et Plasticité dans le Système Nerveux Central, Institut National de la Santé et de la Recherche Médicale Unité 536, 17 rue du Fer à Moulin, 75005 Paris, France.

Copyright (C) 2002 Society for Neuroscience 0270-6474/02/228911-11\$15.00/0
}

as well as by overexpression of a dominant-negative version of MEK, thus implicating the Ras/ERK signaling cascade in this process. Furthermore, overexpression of a mutant form of Akt that cannot be activated impaired cAMP response elementbinding protein (CREB) phosphorylation induced by SKF38393 and quinpirole treatments. Activation of Akt on $\mathrm{Thr}^{308}$ was also found in vivo in striatal neurons after acute administration of cocaine, a psychostimulant that strongly increases DA transmission. Thus, multiple intracellular pathways can transduce signals from dopamine receptors to CREB in striatal neurons, one of these being Akt. We propose that this signaling pathway plays a pivotal role in DA-induced regulation of gene expression and long-term neuronal adaptation in the striatum.

Key words: extracellular signal-regulated kinase; phospho$T_{\text {Thr }}^{308}$ Akt; PI3-kinase; cAMP; gene regulation; nuclear translocation; cocaine ker and Cantley, 1997; Falasca et al., 1998). This binds to the PH domain of Akt and promotes its translocation from the cytosol to the plasma membrane, where its is activated by phosphorylation on two critical residues, $\mathrm{Thr}^{308}$ and $\mathrm{Ser}^{473}$. Then, Akt detaches from the membrane and targets both cytosolic and nuclear substrates. Within the nucleus, Akt controls expression of genes involved in cell survival via the transcription factors Forkhead, NF- $\kappa \mathrm{B}$, and cAMP response element-binding protein (CREB) (for review, see Brunet et al., 2001).

The dopaminergic system plays a significant role in motor function and associative learning (for review, see Berke and Hyman, 2000). Alteration in dopamine signaling has been involved in many neuropsychiatric disorders, including Parkinson's disease, schizophrenia, and attention deficit hyperactivity disorder, as well as drug addiction. One mechanism that underlies the dopaminergic regulation of physiology involves gene regulation, which can contribute to the long-term changes in synaptic plasticity observed during these disorders. Through the stimulation of D1 and D2 subfamilies of G-protein-coupled receptors, dopamine can activate CREB phosphorylation and gene transcription via distinct mechanisms. By elevating intracellular cAMP levels and activating PKA, DA-D1 receptor stimulation leads to phosphorylation of cAMP response element-binding protein (CREB) (Konradi et al., 1994). On the other hand, although D2 receptors are classically linked to reduction of cAMP production, they can couple to phospholipase $\mathrm{C} \beta$ (PLC $\beta$ ) via $\mathrm{G}_{\mathrm{q}}$, mobilize intracellular calcium stores, and also phosphorylate CREB (Yan et al., 1999). 
The mitogen-activated protein kinase (MAPK) of the extracellular signal-regulated kinase (ERK) family, a serine/threonine kinase classically associated with cell proliferation and survival, is also a possible downstream effector of both D1 and D2 receptor stimulation (Yan et al., 1999; Zanassi et al., 2001). In this way, it is now well established that in post-mitotic neurons, this signaling cascade can have important roles in gene regulation and synaptic plasticity underlying cognitive functions such as learning and memory, as well as drug addiction (for review, see Valjent et al., 2001).

In non-neuronal cells, certain survival stimuli activate Akt independently of PI3-kinase, including agonists of the PKA pathway (Moule et al., 1997; Sable et al., 1997; Filippa et al., 1999), as well as increases in cytoplasmic calcium levels (Yano et al., 1998). We thus investigated in the present study a possible activation of Akt by DA. We show a rapid activation and nuclear translocation of Akt after both D1 and D2 agonist treatments. In both cases, this activation is independent of PI3-kinase, instead depending on cAMP production for D1 receptors and ERK activation for both D1 and D2 receptor stimulation. Overexpression of a dominant-negative form of Akt diminishes CREB phosphorylation induced by the dopaminergic agonists. Together with the in vivo observation that systemic administration of cocaine also activates Akt in striatal neurons, our data strongly support the possibility that this pathway represents a new route to CREB phosphorylation downstream of DA transmission.

\section{MATERIALS AND METHODS}

Chemicals and reagents. U0126 (Calbiochem) and wortmannin (Calbiochem), were diluted in DMSO. Rp-cAMP (Sigma) was diluted in $\mathrm{H}_{2} \mathrm{O}$. For each treatment, cells were incubated with the inhibitors, 15 (wortmannin) or 30 (other inhibitors) min before the addition of SKF38393 (RBI), quinpirole (RBI), or insulin growth factor 1 (IGF-1; RBI).

Neuronal cell cultures and treatments. Striata were dissected out from 14-d-old Swiss mouse embryos (Janvier) and mechanically dissociated by gently pipetting in modified L-15 medium. After decantation for $10 \mathrm{~min}$ at room temperature (RT) to eliminate tissue debris, cells were collected by centrifugation at $1000 \times g$ for $5 \mathrm{~min}$. Cell pellets were suspended in Neurobasal medium [B27 supplement (Invitrogen), $500 \mathrm{~nm}$ L-glutamine, $60 \mu \mathrm{g} / \mathrm{ml}$ penicillin $\mathrm{G}, 25 \mu \mathrm{M} \beta$-mercaptoethanol] and then plated into 24 -well $\left(1.8 \times 10^{5}\right.$ cells per well) or 6 -well $\left(8.6 \times 10^{5}\right.$ cells per well $) \mathrm{Nunc}$ multi-well plates coated with $10 \mu \mathrm{g} / \mathrm{ml}$ poly-D-lysine (Sigma). After removal of the coating solution, cells were seeded in the Neurobasal medium and cultured at $37^{\circ} \mathrm{C}$ in a humidified atmosphere of $95 \%$ air and $5 \% \mathrm{CO}_{2}$ and were used after $8 \mathrm{~d}$ in vitro (DIV), when most of the cells were of neuronal phenotype with no detectable glial elements. On the day of the experiments, the medium was removed and replaced by Neurobasal medium containing SKF38393 $(100 \mu \mathrm{M})$ (Paolillo et al., 1998; Zanassi et al., 2001) and quinpirole (10 $\mu \mathrm{M})$. Then cells were replaced at $37^{\circ} \mathrm{C}$ for the appropriate time. Inhibitors were added before agonist treatments as detailed above.

Immunocytochemistry. After the appropriate time of agonist treatment, cells were fixed in 24-well plates with PBS containing $4 \%$ paraformaldehyde (PFA) for $40 \mathrm{~min}$ at RT and then incubated with methanol/ acetone solution $(50: 50)$ for $10 \mathrm{~min}$ at $4^{\circ} \mathrm{C}$. After three rinses in PBS, cells were treated with blocking buffer (fetal calf serum $10 \%$, BSA $1 \%$ in PBS) for $2 \mathrm{hr}$ at RT. Polyclonal antibodies raised against phospho-Thr ${ }^{308}$ Akt (P-T-Akt, 1:1000; UBI, Euromedex), phospho-Ser ${ }^{473}$ Akt (P-S-Akt, 1:200; Promega), phospho-Ser ${ }^{133}$ CREB (P-CREB, 1:1000; UBI, Euromedex), and dually phosphorylated ERK ( $\mathrm{Thr}^{202}-\mathrm{Tyr}^{204} \mathrm{p} 44 / 42$ MAPK) (P-ERK, 1:500; New England Biolabs, Ozyme, France) were incubated overnight $(\mathrm{ON})$ at $4^{\circ} \mathrm{C}$ in PBS containing $1 \%$ BSA, $0.05 \%$ Tween 20. Then, anti-rabbit Cy3-conjugated antibodies (1:750; Amersham) were incubated for $2 \mathrm{hr}$ at RT. For control of the specificity of P-T-Akt antibody, $10 \mu \mathrm{g}$ of immunogen peptide corresponding to amino acids KDGATMK[pT]FCGT or $10 \mu \mathrm{g}$ of nonactive Akt 1-glutathione $S$-transferase (GST) agarose protein (UBI, Euromedex) was preincubated for $30 \mathrm{~min}$ at RT with $1 \mu \mathrm{g}$ of P-T-Akt antibody. For double immunostaining, a polyclonal antibody raised against P-T-Akt was incu- bated simultaneously with a monoclonal antibody raised against P-ERK $\left(\mathrm{Thr}^{202}-\mathrm{Tyr}^{204} \mathrm{p} 44 / 42 \mathrm{MAPK}\right)$ (1:500, Sigma). Plates were rinsed in PBS and incubated sequentially with an anti-rabbit $\mathrm{Cy} 3$-conjugated antibody (1:750; Amersham) and an anti-mouse FITC-conjugated antibody (1: 500; Sigma) for $2 \mathrm{hr}$ each at RT. After counterstaining with Hoechst, cells were mounted under coverslips using Vectashield (Vector Abcys).

Subcellular fractionation. Neurons were cultured in six-well plates, placed on ice, and lysed in buffer A containing 5 mM HEPES, pH 7.9, 1.5 $\mathrm{mM} \mathrm{MgCl}_{2}, 10 \mathrm{mM} \mathrm{KCl}$, and a mix of protease and phosphatase inhibitors (100 $\mathrm{mM} \mathrm{Na}_{3} \mathrm{VO}_{4}, 0.5 \mathrm{~mm}$ DTT, $100 \mathrm{~nm}$ okadaic acid, $2.5 \mu \mathrm{g} / \mathrm{ml}$ aprotinin, $2.5 \mu \mathrm{g} / \mathrm{ml}$ pepstatin, $0.5 \mathrm{~mm}$ PMSF, $0.5 \mathrm{~mm}$ benzamidine, $2.5 \mu \mathrm{g} / \mathrm{ml}$ leupeptin, $1 \mu \mathrm{M}$ microcystin L-R). Lysates were centrifuged for $10 \mathrm{~min}$ at $4000 \times g$ at $4^{\circ} \mathrm{C}$. The supernatant corresponding to the cytosolic fraction was removed, and pellets were washed twice with buffer A and suspended in buffer B containing $20 \mathrm{~mm}$ HEPES, $\mathrm{pH} 7.9,20 \%$ glycerol, $0.1 \mathrm{M} \mathrm{KCl}$, $0.5 \mathrm{mM} \mathrm{MgCl}_{2}$, and the same mix of protease and phosphatase inhibitors as buffer A. Pellets were washed twice and suspended in buffer $\mathrm{C}$ containing $20 \mathrm{~mm}$ HEPES, pH 7.9, 25\% glycerol, $0.5 \mathrm{~mm} \mathrm{NaCl}, 0.5 \mathrm{~mm}$ $\mathrm{MgCl}_{2}, 0.5 \mathrm{~mm}$ EDTA, and a mix of protease and phosphatase inhibitors. This fraction corresponded to the nuclear fraction. Protein extracts (10 $\mu \mathrm{g}$ from each fraction) were separated by $10 \%$ SDS-PAGE before electrotransfer. Blots were blocked with 5\% nonfat milk and incubated with rabbit polyclonal antisera raised against phospho- $\mathrm{Thr}^{308}$ Akt (1:1000; $\mathrm{UBI}) \mathrm{ON}$ at $4^{\circ} \mathrm{C}$. After rinsing, the blots were incubated with goat horseradish peroxidase-conjugated antibody (1:5000; Amersham Biosciences) for $2 \mathrm{hr}$ at RT before exposure to the ECL kit (Amersham Biosciences).

Immunoprecipitation and in vitro kinase assay. Cells were lysed in lysis buffer $(10 \mathrm{~mm}$ Tris-HCl, $50 \mathrm{~mm} \mathrm{NaCl}, 1 \%$ Triton $\mathrm{X}-100,30 \mathrm{~mm}$ sodium pyrophosphate, $50 \mathrm{~mm} \mathrm{NaF}, 5 \mu \mathrm{M} \mathrm{ZnCl}, 100 \mu \mathrm{M} \mathrm{Na} \mathrm{VO}_{4}, 1 \mathrm{~mm}$ DTT, $5 \mathrm{nM}$ okadaic acid, $0.5 \mu \mathrm{M}$ PMSF, $0.5 \mathrm{~mm}$ benzamidine, $1 \mu \mathrm{M}$ microcystin $\mathrm{L}-\mathrm{R}, 2.5 \mu \mathrm{g} / \mathrm{ml}$ aprotinin, pepstatin, and leupeptin). Insoluble cell debris was removed by centrifugation at $13,000 \times g$ for $15 \mathrm{~min}$ at $4^{\circ} \mathrm{C}$. Onehundred micrograms of striatal lysates were incubated overnight at $4^{\circ} \mathrm{C}$ with $2 \mu \mathrm{g}$ of anti-Akt/PKB, PH domain antibody (UBI, Euromedex) previously coupled to protein G-Agarose. Immunoprecipitates were washed three times with lysis buffer and twice in buffer B containing 50 $\mathrm{mm}$ Tris-HCl, $\mathrm{pH} 7.5,0.03 \%$ (w/v) Brij-35, $0.1 \mathrm{~mm}$ EGTA, and 0.1\% $(\mathrm{v} / \mathrm{v})$ 2-mercaptoethanol. Then, immunoprecipitates were resuspended in kinase buffer (50 mm Tris-HCl, pH 7.5, 0.02\% Brij-35, 0.1 mm EGTA, 10 $\mathrm{mm} \mathrm{Mg}\left(\mathrm{C}_{2} \mathrm{H}_{3} \mathrm{O}_{2}\right)_{2}, 20 \mu \mathrm{M}$ ATP, $10 \mu \mathrm{M}$ cAMP-dependent kinase (PKA) inhibitor, $2 \mathrm{mM}$ DTT, $5 \mathrm{nM}$ okadaic acid, $100 \mu \mathrm{M} \mathrm{Na} \mathrm{VO}_{4}, 2.5 \mu \mathrm{g} / \mathrm{ml}$ aprotinin, pepstatin, and leupeptin). The suspended immunoprecipitates were incubated with $4 \mu \mathrm{M}\left[\gamma^{-32} \mathrm{P}\right]$ ATP $(3000 \mathrm{Ci} / \mathrm{mmol}$; DuPont NEN) and $2 \mu \mathrm{g}$ of recombinant GST-CREB (aa 1-166) bound to glutathioneagarose at RT for $30 \mathrm{~min}$. The reactions were stopped by dilution with $500 \mu \mathrm{l}$ HBB (20 mm HEPES, pH 7.6, $2.5 \mathrm{~mm} \mathrm{MgCl}_{2}, 50 \mathrm{~mm} \mathrm{NaCl}, 0.05 \%$ Triton X-100, $20 \mathrm{~mm} \beta$-glycerol phosphate, $10 \mathrm{~mm} p$-nitrophenyl phosphate). After two washes with HBB, samples were denatured and analyzed on $10 \%$ SDS-PAGE. The gel was Coomassie stained to confirm equal amounts of substrate in all lanes and dried. The GST-CREB ${ }_{1-166}$ protein preparation also contains a truncated protein containing primarily GST that showed no labeling.

Transfections and DNA constructs. Dominant-negative Akt (DN-Akt) was hemagglutinin (HA)-tagged $\mathrm{PKB} \alpha, \mathrm{Asp}^{179} / \mathrm{Ala}^{-T h r}{ }^{308} / \mathrm{Ala}-\mathrm{Ser}^{473} /$ Ala cloned in the mammalian expression vector pCMV5 (kindly provided by Dr. Dario R Alessi, Dundee, UK) (Andjelkovic et al., 1997). Expression of DN-Akt was visualized by immunocytochemical detection of HA using a monoclonal anti-HA antibody (1:2000; Boehringer Mannheim) and revealed by anti-mouse Cy3-conjugated antibody (1:600; Jackson ImmunoResearch, Intershim). Dominant-negative form of mitogenactivated protein kinase kinase (DN-MEK), S222A, was from Drs. G. Pagès and J. Pouyssegur (Pagès et al., 1994). Transient transfection of primary striatal cultures was performed with Lipofectamine 2000 (Invitrogen). Cells $\left(1.8 \times 10^{5}\right)$ were transfected with $1 \mu \mathrm{g}$ of green fluorescent protein (GFP) plasmid (pEGFP-N3, Clontech) or cotransfected with $1 \mu \mathrm{g}$ of GFP plasmid and $5 \mu \mathrm{g}$ of DN-Akt or DN-MEK plasmid with Lipofectamine 2000 as recommended by the manufacturer's protocol. After $6 \mathrm{hr}$, the cultures were rinsed with fresh medium. After $24 \mathrm{hr}$, cells were treated with SKF38393 or quinpirole as described above.

Immunocytochemical and statistical analysis. For each experiment, cells were analyzed under a fluorescent inverted microscope (Nikon) directly into the wells. Images from immunofluorescence were digitized (magnification $400 \times$ ) in parallel with Hoechst staining, from five independent fields for each experiment ( $n=3$ for each treatment). The percentage of 
P-T-Akt- or P-ERK-positive neurons was calculated by comparison with total Hoechst-stained neurons. Data were analyzed using one-way ANOVA between subjects, and post hoc comparisons were made using the Newman-Keuls test. In all cases, significance was set at $p<0.05$.

In vivo analysis: animals, drugs, and treatments. Animal care was conducted in accordance with the standard ethical guidelines (National Institutes of Health, publication 85-23, revised 1985, and European Community Guidelines on the Care and Use of Laboratory Animals) and approved by the local ethics committee. Male CD-1 mice (22-24 gm) (Charles River) were intraperitoneally injected with cocaine $(20 \mathrm{mg} / \mathrm{kg}$; Sigma) dissolved in $0.9 \% \mathrm{NaCl}$.

Tissue preparation and immunohistochemistry. Tissue preparation was performed as described by Valjent et al. (2000). Briefly, mice were rapidly anesthetized by intraperitoneal injection of pentobarbital (Sanofi) before intracardiac perfusion of $4 \%$ PFA in $0.1 \mathrm{M} \mathrm{Na}_{2} \mathrm{HPO}_{4} /$ $\mathrm{NaH}_{2} \mathrm{PO}_{4}$ buffer, pH 7.5, delivered with a peristaltic pump at $20 \mathrm{ml} / \mathrm{min}$ for $5 \mathrm{~min}$. Brains were then postfixed overnight in the same fixative solution and stored at $4^{\circ} \mathrm{C}$. Sections $(30 \mu \mathrm{m})$ were cut with a Vibratome (Leica) and then kept in a solution containing 30\% ethylene glycol, $30 \%$ glycerol, $0.1 \mathrm{~m}$ phosphate buffer, and $0.1 \%$ diethylpyrocarbonate (Sigma, Deisenhofen, Germany) at $-20^{\circ} \mathrm{C}$ until they were processed for immunohistochemistry as described by Valjent et al. (2000). For detection of phosphorylated proteins, $0.1 \mathrm{~mm} \mathrm{NaF}$ was included in all buffers and incubation solutions. On day 1 , free-floating sections were rinsed in Tris-buffered saline (TBS; $0.25 \mathrm{M}$ Tris and $0.5 \mathrm{NaCl}, \mathrm{pH} \mathrm{7.5)}$ ) and incubated for 15 min with $0.2 \%$ Triton X-100 in TBS. After three rinses, floating sections were saturated for $1 \mathrm{hr}$ with $3 \%$ BSA, $0.2 \%$ Triton in TBS. Then, the sections were rinsed three times in TBS and incubated with the primary antibody (P-T-Akt, 1:500; UBI, Euromedex) overnight at $4^{\circ} \mathrm{C}$ in TBS containing $1 \%$ BSA and $0.1 \%$ Triton. On day 2 , after three rinses in TBS, sections were incubated for $2 \mathrm{hr}$ at room temperature with the anti-rabbit Cy3-conjugated antibody (1:250; Amersham). After three rinses in TBS, tissue sections were mounted under coverslips using Vectashield (Vector) for fluorescent confocal microscopic examination.

\section{RESULTS}

\section{Effects of D1 and D2 receptor stimulation on phosphorylation levels of Akt in striatal neurons}

Akt activation in response to mitogenic factors is mediated by PI3-kinase, which phosphorylates Akt on two critical residues, Ser ${ }^{473}$ and $\mathrm{Thr}^{308}$ (Alessi et al., 1996; Alessi and Cohen, 1998). To determine whether DA agonists could activate Akt in striatal neurons, we used immunocytochemical detection with antibodies that specifically recognize P-T-Akt and P-S-Akt. We chose doses of DA-D1 $(100 \mu \mathrm{M})$ and DA-D2 $(10 \mu \mathrm{M})$ agonists known to activate ERK in striatal neurons (Yan et al., 1999; Zanassi et al., 2001).

Primary striatal neurons in culture showed very low immunoreactivity for both antibodies in control conditions. Although P-T-Akt immunoreactivity was strongly and rapidly increased after incubation with the selective D1 receptor agonist SKF38393 and D2 receptor agonist quinpirole, we failed to detect any increase in P-S-Akt immunoreactivity by these treatments (Fig. $1 A$ ). In light of this unexpected observation, we analyzed the effect of IGF, which strongly activates Akt on both $\mathrm{Ser}^{473}$ and $\mathrm{Thr}^{308}$ residues (Alessi et al., 1996). In contrast to DA agonists, IGF treatment increased the levels of both P-T-Akt and P-S-Akt in striatal neurons (Fig. $1 A$ ).

Thus D1 and D2 agonists induced phosphorylation of Akt solely on $\mathrm{Thr}^{308}$. To confirm the specificity of the immunocytochemical staining by the P-T-Akt antibody, we added an excess of the peptide corresponding to phosphorylated $\mathrm{Thr}^{308}$ as well as the surrounding amino acids (KDGATMK[pT]FCGT) that completely blocked the immunoreactivity induced by the D1 (Fig. 1B) and D2 (data not shown) agonists. The specificity of P-T-Akt antibody was further confirmed using an excess of nonactive Akt1-GST protein that did not block P-T-Akt immunolabeling (Fig. $1 B$ ). The $\mathrm{Thr}^{308}$ residue lies within the Akt activation loop, a region that when unphosphorylated negatively regulates the kinase activity of Akt. Therefore, phosphorylation of $\mathrm{Thr}^{308}$ by upstream kinases offers an alternative mechanism to activate Akt. Accordingly, phosphorylation of Akt at $\mathrm{Thr}^{308}$ is sufficient to trigger activation of specific substrates for Akt in some model systems (Yano et al., 1998; Filippa et al., 1999), an observation that we further confirmed using a kinase assay (see Fig. 6A).

P-T-Akt immunostaining was localized to the nucleus. To confirm this biochemically, we fractionated striatal extracts into the nucleus and the cytoplasm. As a control of our fractionation procedure, CREB immunoblotting was performed and showed an immunoreactive band at $45 \mathrm{kDa}$, the expected molecular weight for $\mathrm{CREB}$, in the nuclear extract exclusively. From these fractions, we then analyzed the distribution of P-T-Akt by immunoblotting. This revealed a strong increase in nuclear P-T-Akt after D1, D2, and IGF treatments (Fig. 1C), corresponding to the nuclear labeling found by immunocytochemistry (Fig. 1A). The cytosolic fraction showed considerable reactivity even in the control extract, in contrast to the immunocytochemical analysis, which suggests that this reactivity is nonspecific and a consequence of the denaturing conditions of SDS-PAGE.

P-T-Akt-immunoreactive nuclei were quantified and corresponded to $25 \%(p<0.05)$ and $40 \%(p<0.01)$ of striatal neurons at 10 and 20 min of D1 agonist application, respectively (Fig. 1D). Positive nuclei for P-T-Akt appeared with the same kinetics for the D2 agonist and occurred in 21 and $26 \%$ of striatal neurons after $10 \mathrm{~min}(p<0.05)$ and $20 \mathrm{~min}(p<0.05)$ of quinpirole treatment, respectively (Fig. $1 D)$.

\section{D1 and D2 receptor stimulation coactivate Akt and ERK in the same striatal neurons}

Similarly to Akt, several recent reports indicate that the ERK signaling pathway is activated in response to $\mathrm{D} 1$ and $\mathrm{D} 2$ receptor stimulation in striatal neurons (Yan et al., 1999; Zanassi et al., 2001). In these studies, ERK1 and ERK2 activation were analyzed by immunoblotting with an antibody that specifically labels their dually phosphorylated, activated form, namely anti-phospho $\mathrm{Tyr}^{202}$-Thr ${ }^{204}$ ERKs. Using this antibody for immunocytochemical analysis, we found activated ERKs localized to the nucleus at 20 min, after both D1 and D2 agonist treatments (Fig. 2A-C). Interestingly, double immunolabeling for activated Akt (polyclonal antibody directed against phospho $\mathrm{Thr}^{308} \mathrm{Akt}$; revealed by anti-rabbit $\mathrm{Cy} 3$ ) and activated ERKs (monoclonal antibody directed against phospho $\mathrm{Tyr}^{202}$-Thr ${ }^{204}$ ERKs; revealed by antimouse FITC), showed colocalization of P-ERK and P-T-Akt immunolabeling after incubation with DA agonists (Fig. 2A).

These results show that ERKs and Akt activation occur in the same striatal population in response to D1 and D2 stimulation. They also implicate these two intracellular signaling pathways as possible downstream effectors of D1 and D2 receptors to nuclear events.

\section{Signaling pathways underlying D1 receptor regulation of Akt phosphorylation}

To assess the role of PI3-kinase in the activation of Akt induced by $\mathrm{D} 1$ receptors, we pretreated the primary cultures with the inhibitor wortmannin at $100 \mathrm{nM}$, a dose that selectively blocks PI3-kinase (Davies et al., 2000). The cultures were then induced for 20 min with D1 agonist or IGF, which correspond to the peak time point for Akt activation. Although wortmannin totally blocked IGF-induced P-T-Akt (Fig. 3A), it caused no reduction in the number of D1-induced P-T-Akt-immunoreactive neurons 


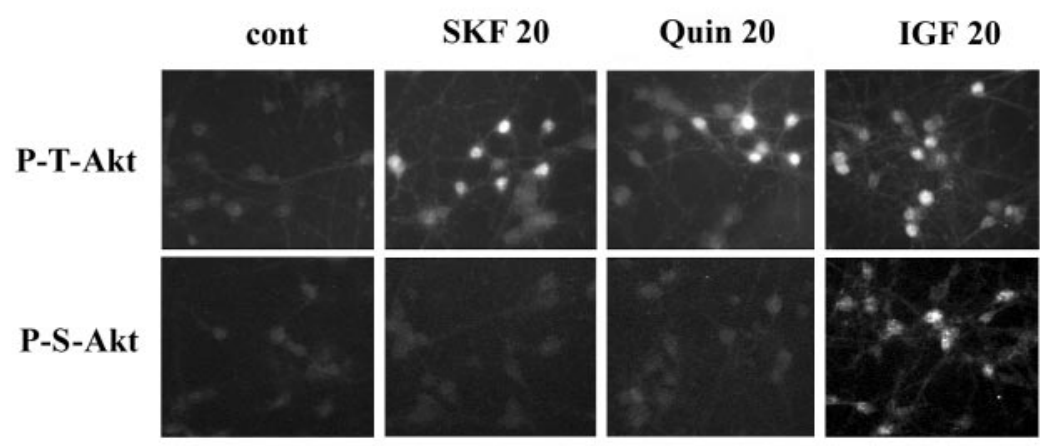

B

cont
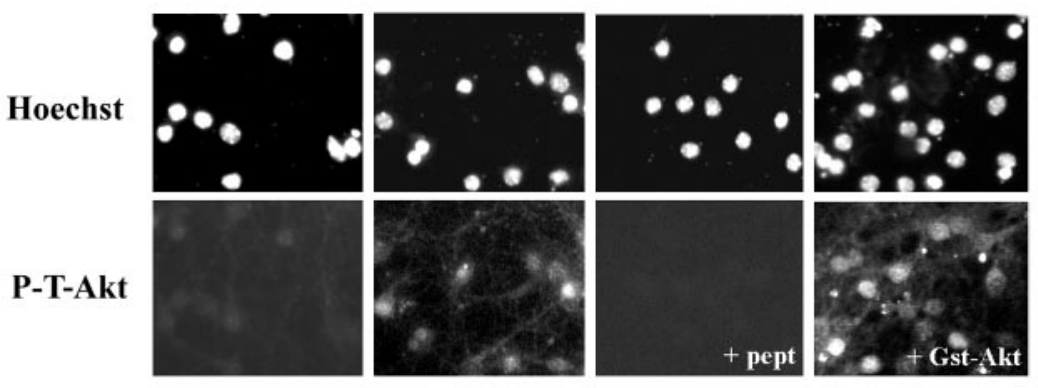

C

P-T-Akt -

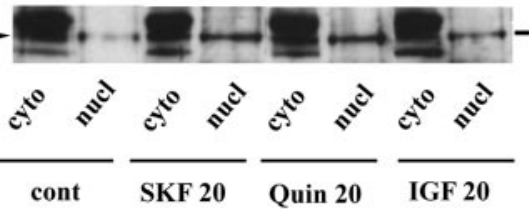

$63 \mathrm{kDa}$

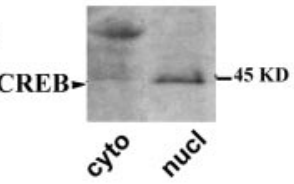
excess of the immunogen peptide: KDGATMK[pT] FCGT (+pept) or unphosphorylated GST-Akt1 $(+G s t-A k t)$ (bottom panel). C, Western blot analysis of P-T-Akt from subcellular fractionation of striatal neurons. Specific labeling corresponding to the expected molecular weight for Akt was detected in the nuclear compartment during SKF38393, quinpirole, and IGF treatment. As a control of fractionation, CREB immunoblotting was performed showing a specific nuclear immunostaining. $D$, P-T-Akt-immunoreactive nuclei were quantified during treatment with the D1 and D2 agonists for $10 \mathrm{~min}$ (SKF 10 and Quin 10, respectively) and $20 \mathrm{~min}$ (SKF 20 and Quin 20, respectively). Data report the percentage of P-T-Akt-positive nuclei when compared with the total number of Hoechst nuclei and are representative of three independent experiments for each treatment. For each experiment, cells were counted from five independent fields $(\sim 100$ cells for each field). Statistical comparisons were performed using one-way ANOVA followed by post hoc comparison (Newman-Keuls test). ${ }^{*} p<0.05$ and ${ }^{* *} p<0.01$ when compared with the control group.

(Fig. $3 A-C$ ). Similar results (data not shown) were observed with LY294002 $(50 \mu \mathrm{M})$, another commonly used but much less potent inhibitor of PI3-kinase (Davies et al., 2000).

D1 receptors elevate intracellular cAMP and thereby activate PKA, which in turn could regulate Akt phosphorylation in striatal neurons. Indeed, preincubation with Rp-cAMP, the selective inhibitor of PKA, totally abolished P-T-Akt immunoreactivity induced by SKF38393 (Fig. 3B-C).

Given the colocalization of P-T-Akt and P-ERK immunolabel-

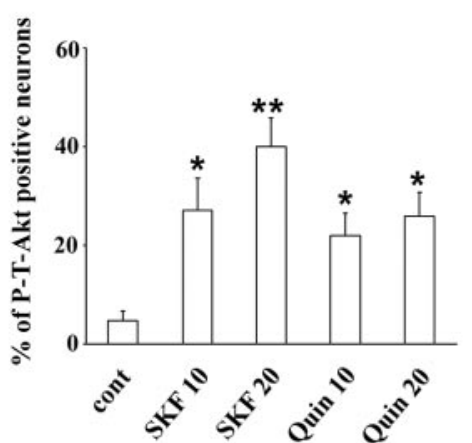

ing (Fig. $2 A, B$ ) we analyzed a possible cross-talk between these two signaling pathways. Striatal neurons were pretreated with U0126, a selective inhibitor of MEK, the activating kinase for ERK1/2 (Favata et al., 1998), before SKF38393 addition. U0126 totally blocked P-ERK immunoreactivity as expected (Fig. 4A) and significantly reduced $(-50 \% ; p<0.01)$ the number of P-TAkt-immunoreactive nuclei (Fig. $3 B, C$ ). A similar reduction in $\mathrm{P}-\mathrm{T}$-Akt-positive neurons was found in cells overexpressing a dominant-negative form of MEK (DN-MEK) (Fig. 3D,E). These 
$\mathbf{A}$

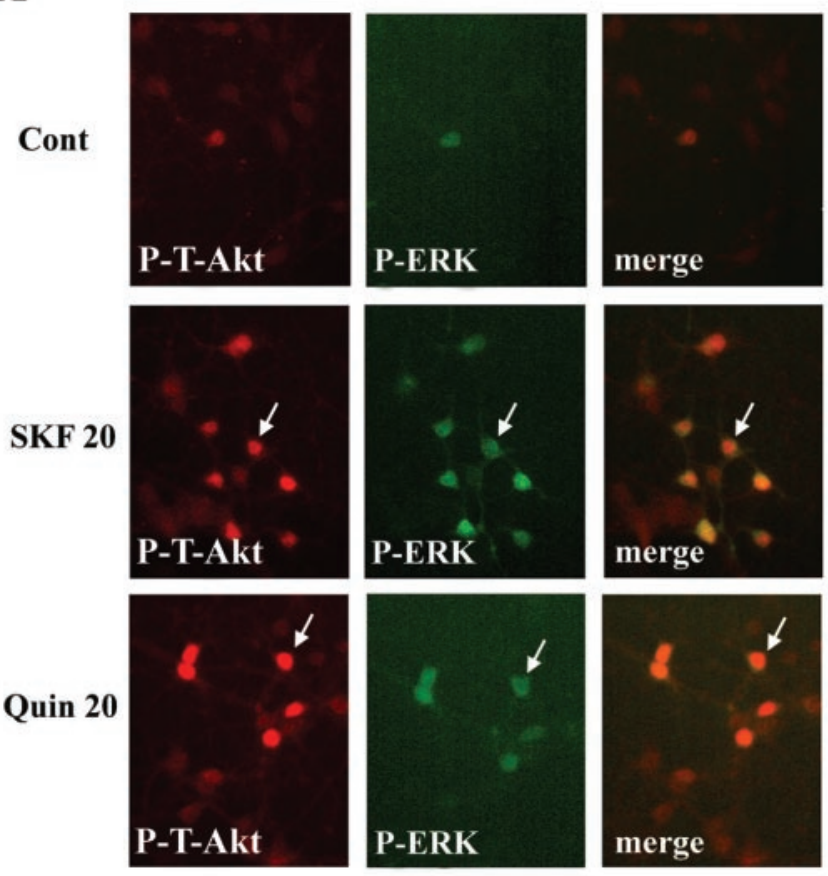

B

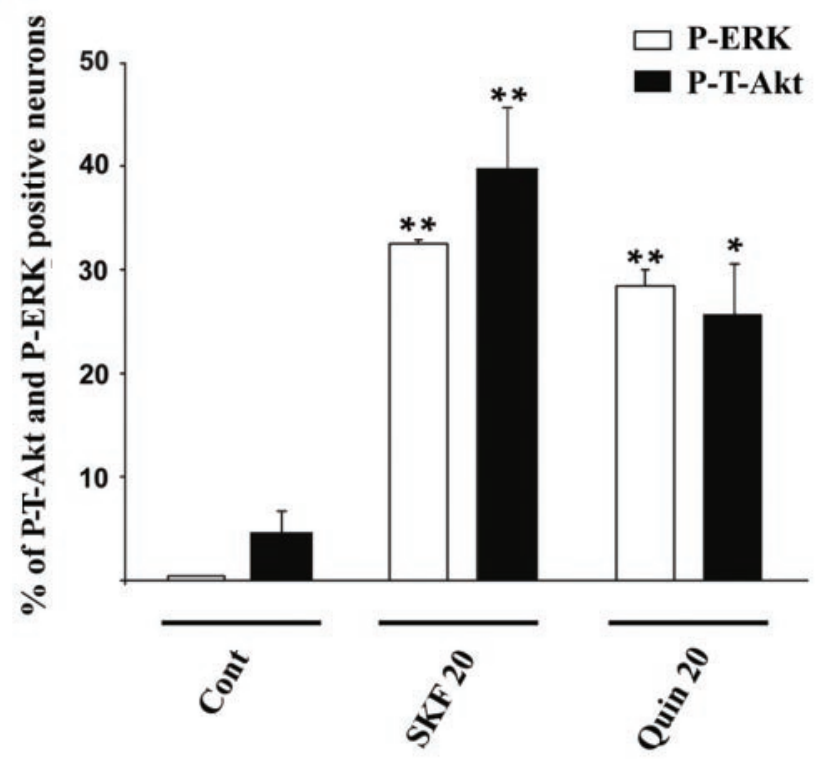

Figure 2. Akt and ERK activation occur in the same striatal subpopulation. $A$, Double immunostaining of active-Akt [polyclonal phospho$\mathrm{Thr}^{308}$ Akt $\left.(P-T-A k t)\right]$ and active-ERK [monoclonal diphospho-Thr ${ }^{202}$ $\mathrm{Tyr}^{204} \mathrm{p} 44 / \mathrm{p} 42$ MAPK $\left.(P-E R K)\right]$ was performed using anti-rabbit Cy3and anti-mouse FITC-coupled secondary antibodies, respectively. Note the colocalization of P-T-Akt and P-ERK immunostaining after $20 \mathrm{~min}$ of treatment with the D1 (SKF 20) and D2 (Quin 20) agonists (arrows). B, Single immunostaining of P-T-Akt and P-ERK was performed using polyclonal phospho-Thr ${ }^{308}$ Akt $(P-T-A k t)$ and polyclonal diphospho$\mathrm{Thr}^{202}-\mathrm{Tyr}^{204} \mathrm{p} 44 / \mathrm{p} 42$ MAPK $(P-E R K)$, respectively. Immunoreactive cells were quantified $20 \mathrm{~min}$ after SKF38393 (SKF 20) and quinpirole (Quin 20) treatments (3 independent experiments each). For each experiment and each antibody, cells were counted from five independent fields ( $\sim 100$ cells for each field). Statistical comparisons: ${ }^{*} p<0.05$ and ${ }^{* *} p<$ 0.01 when compared with the control group (Newman-Keuls test). results indicate that activation of the ERK pathway is involved in the phosphorylation and nuclear translocation of Akt induced by D1 receptor stimulation.

Because recent evidence implicates PI3-kinase in the activation of ERK in striatal neurons (Perkinton et al., 1999), we analyzed the effect of wortmannin on D1-induced ERK activation. As with Akt, the inhibitor did not reduce P-ERK immunoreactivity but actually led to a slight increase (Fig. $4 A, B$ ) that was also observed without D1 agonist treatment (Fig. $4 A, B$ ). This indicates that PI3-kinase exerts a tonic inhibitory control on basal and D1induced ERK activity. Notably, Rp-cAMP pretreatment, which totally inhibited P-T-Akt induction (Fig. 3A,B), only partially reduced (Fig. 4B) $(-50 \% ; p<0.01)$ P-ERK immunoreactivity after D1 agonist treatment.

Thus, D1 receptor signaling to Akt in striatal neurons does not require PI3-kinase activation but instead is totally linked to PKA activation with a contribution of ERK.

\section{Signaling pathways underlying D2 receptor regulation of Akt phosphorylation}

The D2 agonist quinpirole induced P-T-Akt in a subpopulation of striatal neurons (Fig. $1 A, D$ ). Although $\beta \gamma$ subunits of $\mathrm{G}_{\mathrm{o} / \mathrm{i}^{-}}$ coupled receptors activate PI3-kinase in some model systems (Stephens et al., 1994; Hawes et al., 1996; Lopez-Ilasaca et al., 1997), we failed to detect any effect of wortmannin on the induction of either P-T-Akt or P-ERK by quinpirole [(Fig. $5 A, B)$ and data not shown]. In contrast, the MEK inhibitor U0126, applied before quinpirole, totally abolished P-T-Akt (Fig. 5A,B). Similarly, quinpirole-induced P-T-Akt was inhibited in striatal neurons expressing DN-MEK (Fig. 5C,D). Thus, D2 signaling to the $\mathrm{Thr}^{308}$ residue of Akt is entirely coupled to the ERK cascade in our model system.

\section{Overexpression of a dominant-negative form of Akt inhibits CREB phosphorylation induced by D1 but not D2 receptor stimulation}

Although D1 and D2 receptors are differentially coupled to intracellular cAMP production, i.e., positively for D1 and negatively for D2 (Stoof and Kebabian, 1981), CREB phosphorylation at $\mathrm{Ser}^{133}$ can occur in response to stimulation of both DA receptor subtypes. CREB phosphorylation can occur in response to multiple kinases, including PKA, $\mathrm{Ca}^{2+} /$ calmodulin kinases (CaMKs) II and IV, and kinases activated by ERK, such as pp90 ribosomal S6 kinase (RSK) (for review, see Shaywitz and Greenberg, 1999) and mitogen- and stress-activated protein kinase 1 (MSK1) (Deak et al., 1998). In fact, D1 agonist-induced CREB phosphorylation is controlled, at least in part, by ERK (Zanassi et al., 2001), whereas D2 agonist-induced CREB phosphorylation involves the CaMK pathway (Yan et al., 1999).

CREB phosphorylation has recently been shown to occur in response to Akt in vitro as well as in vivo (Du and Montminy, 1998). Given this, we tested whether Akt is linked to CREB phosphorylation induced by DA agonists. As a first assay, we immunoprecipitated Akt from striatal neuron extracts after various treatments and tested its activity toward recombinant GST$\mathrm{CREB}_{1-166}$ (Fig. 6A). This test first confirmed that D1-induced P-T-Akt was associated with increased kinase activity. Furthermore, it showed clearly that CREB was a direct substrate of the activated Akt after D1 agonist treatment. Surprisingly, the D2 agonist failed to activate Akt in this test, a result that could be explained by the low percentage of striatal neurons activated for Akt after this treatment (26\%) (Fig. $1 A-D)$.

We next assayed the effect of transfecting striatal neurons with 
A

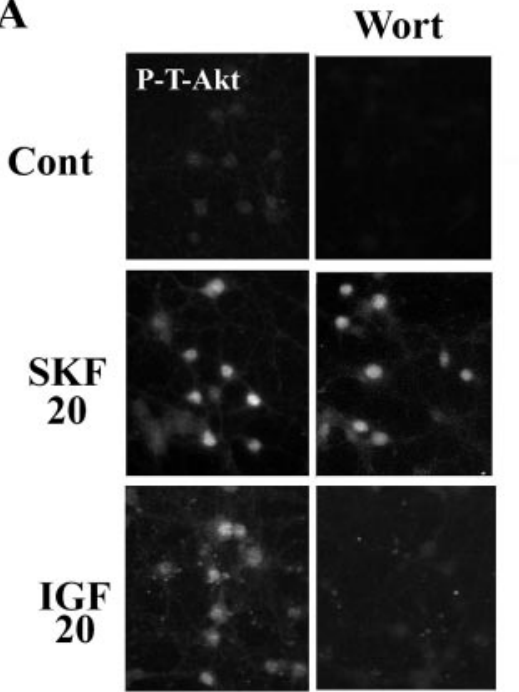

B

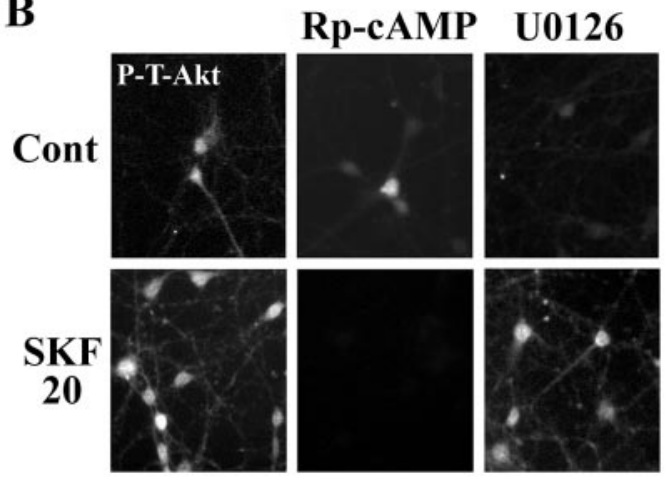

Figure 3. Signaling pathways underlying Akt phosphorylation during D1 receptor stimulation. $A$, Immunocytochemical detection of P-T-Akt was analyzed as described in Figure 1 in the presence of wortmannin (Wort) (100 nM) applied 15 min before D1 agonist or IGF treatment (20 min each) (SKF 20 and IGF 20, respectively). $B$, Immunostaining of P-T-Akt in the presence of the selective inhibitor of PKA, $R p$-cAMP $(50 \mu \mathrm{M})$, or the selective MEK inhibitor, $U 0126(10 \mu \mathrm{M})$. $C$, Quantification of P-T-Akt immunolabeling was performed as described in Figure 1. Statistical analysis: $* p<0.05, * * p<0.01$ when compared with the corresponding control group; ${ }^{\#} p<0.05$ and ${ }^{\# \#} p<0.01$ when compared with SKF38393 treatment alone (NewmanKeuls test). D, P-T-Akt (bottom panel) was analyzed as described in Figure 1 in neurons transfected with GFP (top panel) alone $(G F P)$ or in neurons cotransfected with GFP and DN-MEK (GFP/DN-MEK). Arrowheads indicate the same neuron analyzed with filters corresponding to FITC (for GFP-positive neuron) (top panel) or Cy3 (for P-T-Akt) (bottom panel). Note the disappearance of P-T-Akt immunostaining in cells coexpressing GFP and DN-MEK. $E$, Quantification of P-T-Akt-immunoreactive neurons was performed from GFPor GFP/DN-MEK-transfected neurons $(C$, arrowheads) in control conditions (Cont) and after D1 (SKF 20) agonist treatments. For each experiment, P-T-Akt immunostaining was quantified from 100 transfected cells. Data are representative of three independent experiments for each treatment. ${ }^{* *} p<0.01$ when compared with the control group; ${ }^{\# \#} p<0.01$ when compared with neurons transfected with GFP alone (Newman-Keuls test).

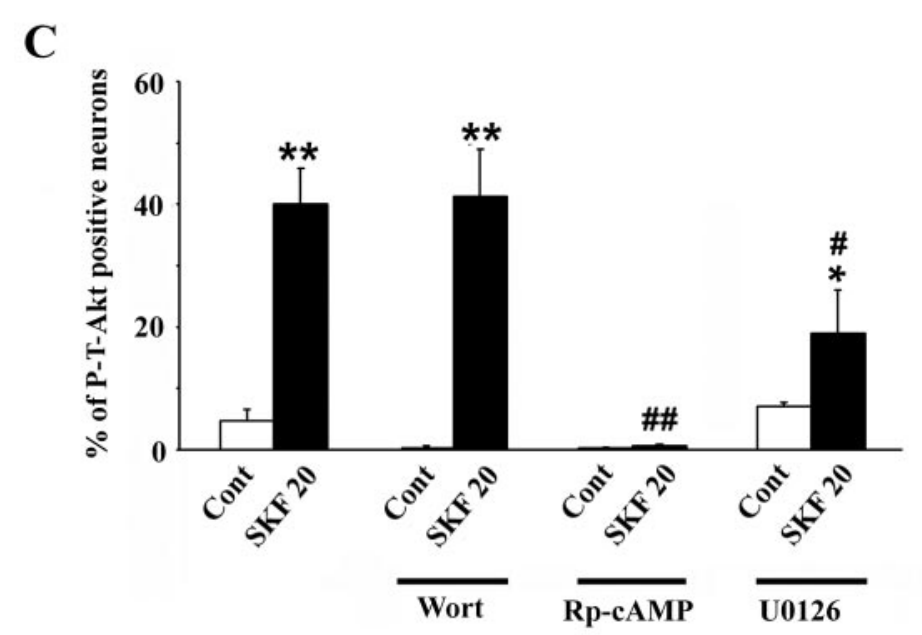

D

Cont
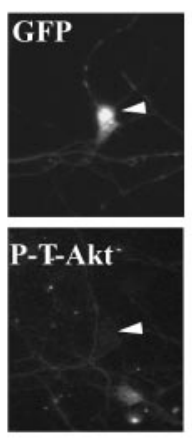
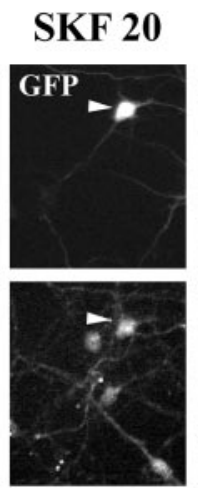
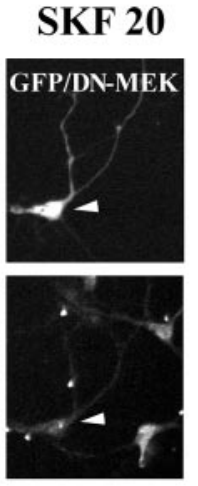

$\mathbf{E}$

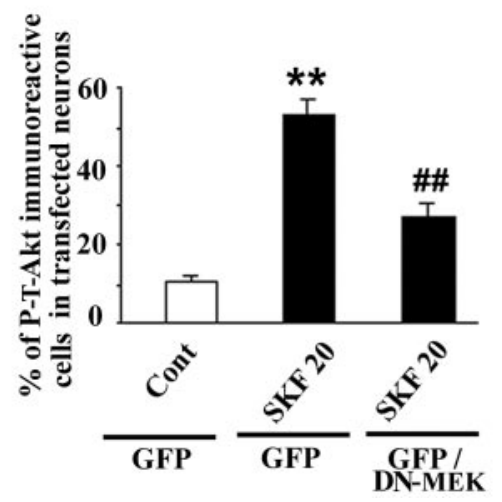

DN-Akt, which lacks most phosphorylation sites for its activation, including $\mathrm{Thr}^{308}$, together with a GFP expression clone to identify the transfected cells. Overexpressed DN-Akt showed both nuclear and cytosolic localization (Fig. 6B), thus illustrating that inactive Akt is found in both compartments. Although Akt has been show to play a key role in cell survival, we failed to detect any apoptotic characteristics in striatal neurons overexpressing DN-Akt (4 vs $3.3 \%$ of apoptotic nuclei in neurons transfected with GFP + DN-Akt when compared with GFP alone).

CREB phosphorylation induced by the DA agonists in cellulo was analyzed by immunocytochemistry, using an anti-P-CREB antibody from neurons transfected with GFP, used as a control for 
A

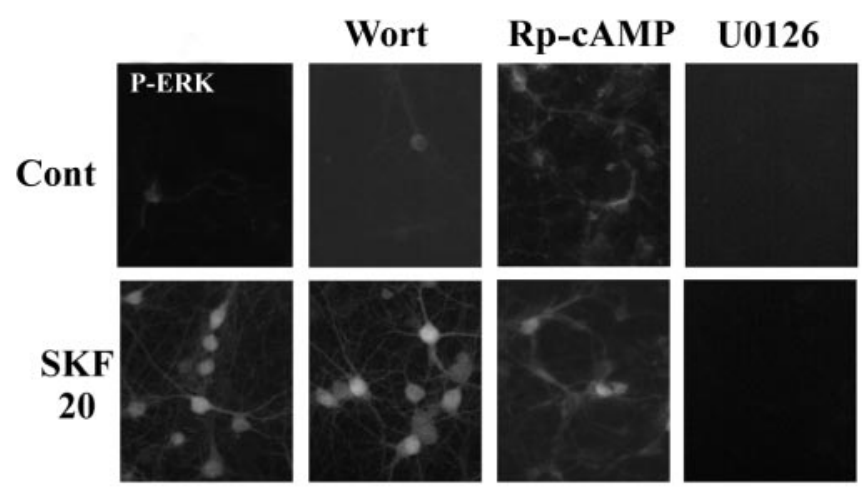

B

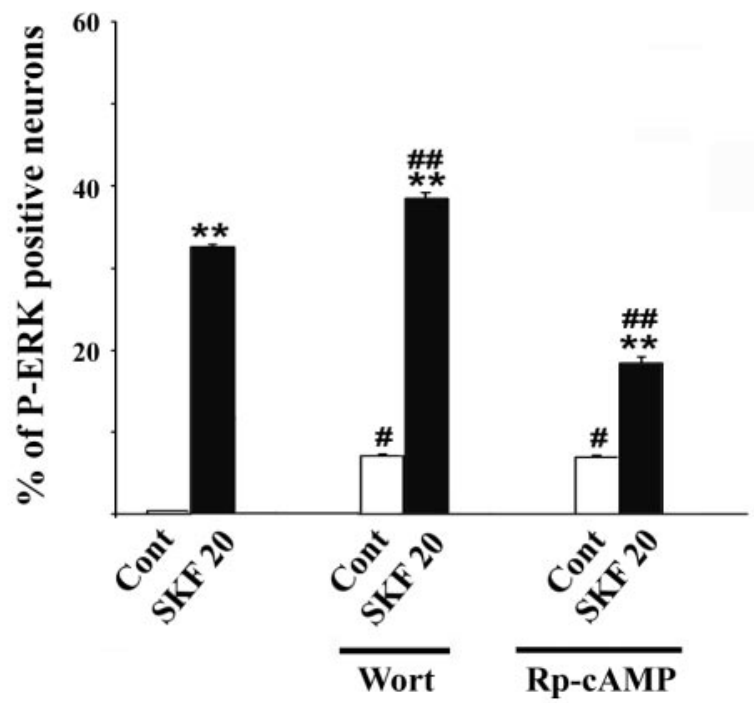

Figure 4. Signaling pathways underlying ERK phosphorylation during D1 receptor stimulation. $A$, Immunocytochemical detection of SKF38393induced P-ERK was analyzed as described in Figure $2 C$, in the presence of wortmannin (Wort) $(100 \mathrm{nM}), R p-c A M P(50 \mu \mathrm{M})$, or U0126 $(10 \mu \mathrm{M}) . B$, Quantification of P-ERK immunolabeling was performed as described in Figure $2 C$. Statistical analysis: ${ }^{*} p<0.05,{ }^{*} p<0.01$ when compared with the corresponding control group; ${ }^{\#} p<0.05$, ${ }^{\# \#} p<0.01$ when compared with groups in the presence or not of the inhibitors (Newman-Keuls test).

transfection. After D1 agonist treatment, striatal neurons, including the transfected neurons positive for GFP, showed a strong increase of CREB phosphorylation in the nucleus (Fig. 6C) after 10 and $20 \mathrm{~min}$. This occurred in 40\% (10 min) and 46\% (20 min) of transfected neurons (Fig. $6 C, D$ ). The D2 agonist treatment also induced CREB activation in the majority of cultured striatal neurons, including the GFP-positive, transfected neurons (52 and $65 \%$ for 10 and 20 min treatment, respectively; $p<0.01$ ) (Fig. $6 C, D)$. More neurons showed P-CREB-positive nuclei after D2 agonist treatment relative to D1 (65 vs $46 \%$ at $20 \mathrm{~min}$ ).

CREB activation was then analyzed in striatal neurons cotransfected with GFP and DN-Akt expression vectors. No CREB activation was found before induction. After D1 agonist treatment, the percentage of P-CREB-immunoreactive nuclei was strongly reduced in cotransfected neurons at both 10 and $20 \mathrm{~min}$ (approximately $-50 \% ; p<0.01$ ) (Fig. $6 C, D$ ). These data impli- cate the Akt pathway as an important effector of CREB phosphorylation in response to D1 stimulation. Quinpirole-induced CREB phosphorylation was unchanged in the presence of DNAkt 10 min after induction, but then showed a slight but significant reduction $(-9 \% ; p<0.05)$ at $20 \mathrm{~min}$ (Fig. 6C,D).

\section{Akt is activated in striatal neurons in vivo}

Having established that Akt was activated by DA agonists in primary striatal neurons in culture, we wished to analyze the physiological relevance of these in vitro observations. For this purpose, we used in vivo administration of cocaine, a psychotrope drug known for its addictive properties. Cocaine considerably increases DA levels in the striatum. Activation of Akt was analyzed after acute cocaine administration, using the same approach as above, i.e., immunocytochemical detection of P-T-Akt and P-S-Akt from striatal sections. Similarly to the in vitro study, no P-S-Akt immunoreactivity was found after acute cocaine administration (data not shown). In striatal sections from mice treated with saline, no P-T-Akt immunoreactivity was found (Fig. 7). This immunoreactivity was increased significantly in striatal neurons, 10 and $20 \mathrm{~min}$ after cocaine administration. Confocal analysis clearly showed nuclear labeling of P-T-Akt at 20 min of cocaine treatment. Thus these data give in vivo evidence that Akt is activated in striatal neurons by DA.

\section{DISCUSSION}

We show here that the activation of Akt occurs in response to both DA-D1 and DA-D2 receptor stimulation in striatal neurons. This activation, which occurs independently of PI3-K, leads to its nuclear translocation where it controls CREB phosphorylation, at least after D1 treatment. Together with the in vivo demonstration that Akt is activated in striatal neurons after acute cocaine treatment, our data provide the first evidence that Akt is an effector of DA signaling to gene expression and thereby provides a new signaling pathway to long-term neuronal adaptation in the striatum.

In our model system, phosphorylation of Akt induced by the D1 agonist was totally dependent on increases in intracellular cAMP levels. This is not the first demonstration that Akt can be activated, i.e., phosphorylated at $\mathrm{Thr}^{308}$ residues by increases of intracellular cAMP levels (Sable et al., 1997) independently of PI3-kinase. It was demonstrated recently that forskolin-induced stimulation of Akt was dependent on PKA, although not directly, because overexpression of the constitutively active catalytic subunit of PKA was able to activate Akt, but mutation of the sole consensus phosphorylation site for PKA into inactive residue did not impair this activation (Filippa et al., 1999).

One possible intermediate could be the ERK pathway, because both the MEK inhibitor U0126 and overexpression of the DNMEK inhibited P-T-Akt immunoreactivity, at least in part. In this way, recent data support the possibility that MSK1, a kinase activated by ERK, controls the activation of Akt (Nomura et al., 2001). Among second messengers that are responsible for the link between D1 receptor stimulation and ERK activation can be the small Ras-related G-protein Rap1, activated by PKA or cAMPguanine nucleotide exchange factor (Kawasaki et al., 1998; Yao et al., 1998; York et al., 1998). However, signaling to ERK by D1 agonists is complex and may also implicate indirect pathways, such as increased levels of intracellular calcium by PKA and subsequent activation of PYK2 and PKC (Zanassi et al., 2001). Besides ERK, increased calcium levels can also activate calciumcalmodulin ( $\mathrm{CaM})$-dependent protein kinases, including $\mathrm{CaM}$ 
A

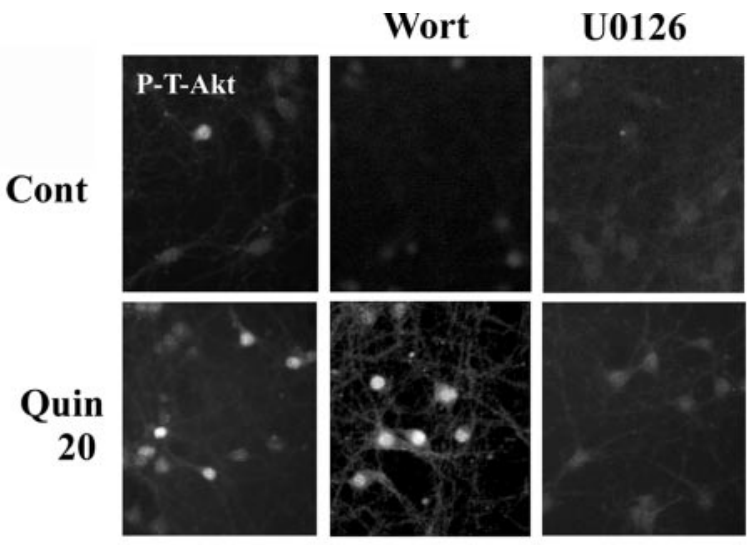

B

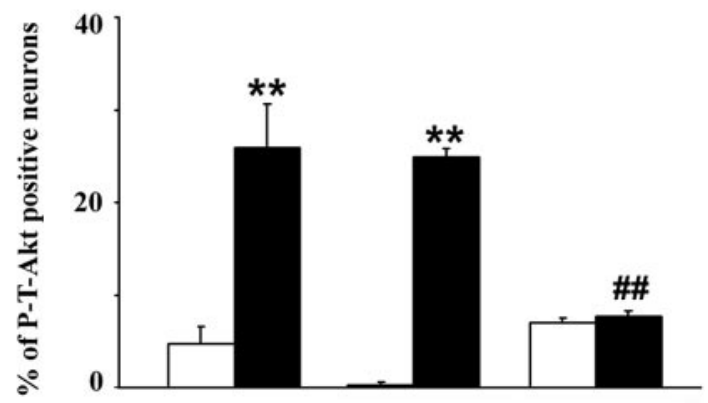

C
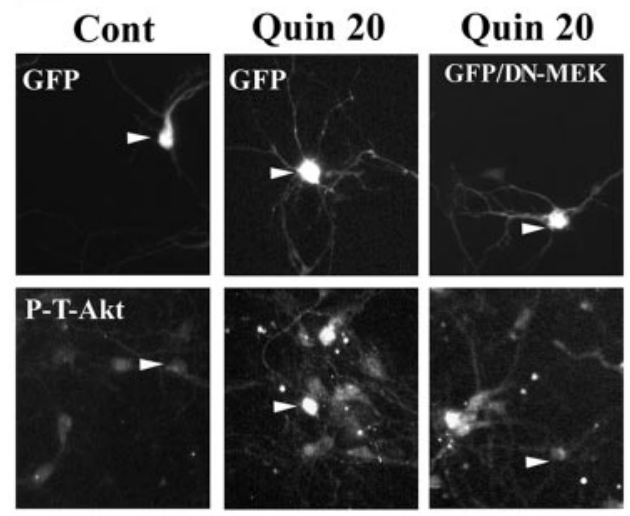

D

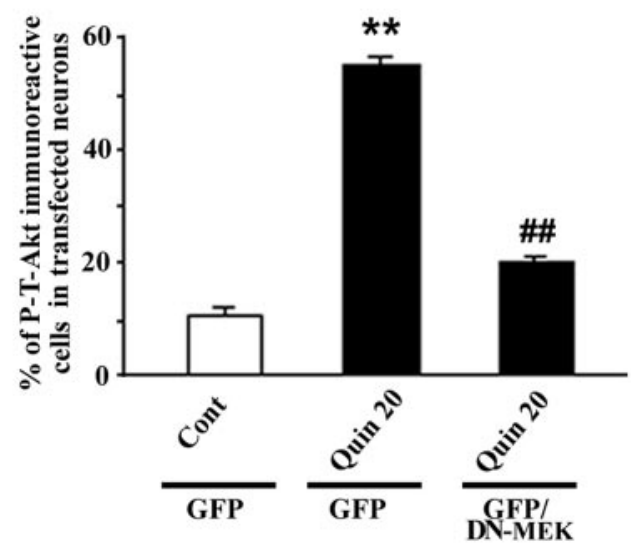

Figure 5. Signaling pathways underlying Akt phosphorylation during D2 receptor stimulation. $A$, Immunocytochemical detection of quinpiroleinduced P-T-Akt was analyzed as described in Figure 1, in the presence of wortmannin (Wort) $(100 \mathrm{nM})$ or U0126 $(10 \mu \mathrm{M})$. B, Quantification of P-T-Akt immunolabeling was performed as described in Figure 1. Statistical analysis: ${ }^{* *} p<0.01$ when compared with the corresponding control group; ${ }^{\# \#} p<0.01$ when compared with SKF38393 treatment alone kinase kinase which is known to phosphorylate directly Akt on $\mathrm{Thr}^{308}$ independently of $\mathrm{Ser}^{473}$, as demonstrated recently in neuroblastoma cell lines (Yano et al., 1998). Thus multiple and complex intracellular intermediates might be responsible for the PKA-dependent activation of Akt that we found in the present study.

We also found an effect of the D2 agonist in the activation of Akt. Studies on other $\mathrm{G}_{\mathrm{o} / \mathrm{i}}$-protein-coupled receptors, including opioid receptors, have shown an important role of the $G \beta \gamma$ subunit as an activator of PI3-kinase activity (Polakiewicz et al., 1998; for review, see Luttrell et al., 1999). In our study, we found no inhibition of D2-induced phosphorylation of Akt by wortmannin, but instead a total inhibition by the MEK inhibitor and the DN-MEK. Of interest, although $\mathrm{G} \beta \gamma$ subunits are also responsible for ERK activation in some model systems (for review, see Luttrell et al., 1999), it was demonstrated recently that D2 receptor signaling to ERK implicates a $\mathrm{G}_{\mathrm{q}}$-protein activation of PLC $\beta$, which in turn can control intracellular calcium levels and activation of PKC (Yan et al., 1999). Thus, it is likely that intracellular signaling by D2 receptor stimulation does not require $\mathrm{G} \beta \gamma$ subunits. Differences in cell lines (Chinese hamster ovary vs primary culture of neurons) as well as experimental procedures (overexpression of a receptor vs natural stimulation) could account for these apparent discrepancies.

An important finding was nuclear translocation of activated Akt after D1 and D2 agonist treatments. Cellular mechanisms underlying phosphorylation of Akt at $\mathrm{Thr}^{308}$ residues have been well studied during growth factor stimulation. They necessitate a preliminary essential step, which is translocation of Akt from the cytosol to the membrane, by a mechanism that requires PI3kinase activation (Hemmings, 1997; Toker and Cantley, 1997; Falasca et al., 1998). This translocation allows a correct conformation for the activating phosphorylation by PDK1. Then Akt detaches from the membrane, which enables it to translocate to the nucleus. In conditions during which Akt is activated independently of PI3-kinase, for example by a PKA-dependent pathway, the same sequence of intracellular events occurs, i.e., translocation to the plasma membrane, followed by its dissociation and nuclear translocation. However, blocking membrane translocation by wortmannin treatment had no effect on the phosphorylation of Akt at $\mathrm{Thr}^{308}$ and failed to affect its nuclear localization (Filippa et al., 1999). Thus, the precise cellular mechanisms underlying nuclear translocation of Akt during stimuli that do not require PI3-kinase activity remain to be established.

During growth factor stimulation, the best characterized nuclear substrates of Akt are Forkhead and CREB (Du and Montminy, 1998; Brunet et al., 1999; for review, see Datta et al., 1999; Brunet et al., 2001). By controlling the phosphorylation state of these transcription factors, Akt is critically involved in cell survival. CREB phosphorylation has long been considered a critical event involved in memory formation (for review, see Mayford and Kandel, 1999) as well as neuronal adaptation to drugs of abuse (Blendy and Maldonado, 1998). Thus, by controlling the tran-

(Newman-Keuls test). $C$, During quinpirole treatment, P-T-Akt (bottom panel) was analyzed as described in Figure 3 in neurons transfected (arrowheads) with GFP alone (GFP) or with GFP and DN-MEK (GFP/ $D N-M E K)$ (bottom panel). D, Quantification of P-T-Akt-immunoreactive neurons in transfected neurons as described in Figure $3 E$. Statistical analysis: ${ }^{* *} p<0.01$ when compared with the control group; ${ }^{\# \#} p<0.01$ when compared with neurons transfected with GFP alone (Newman-Keuls test). 
A

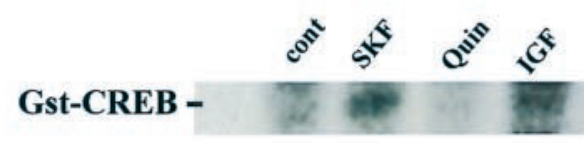

B
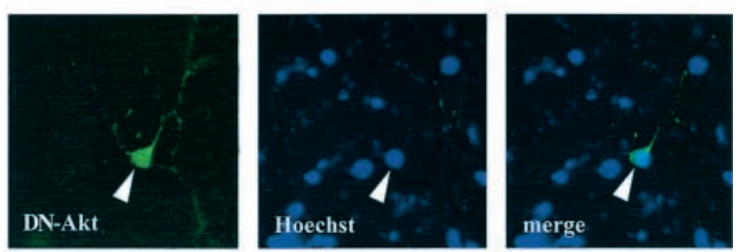

C

Cont
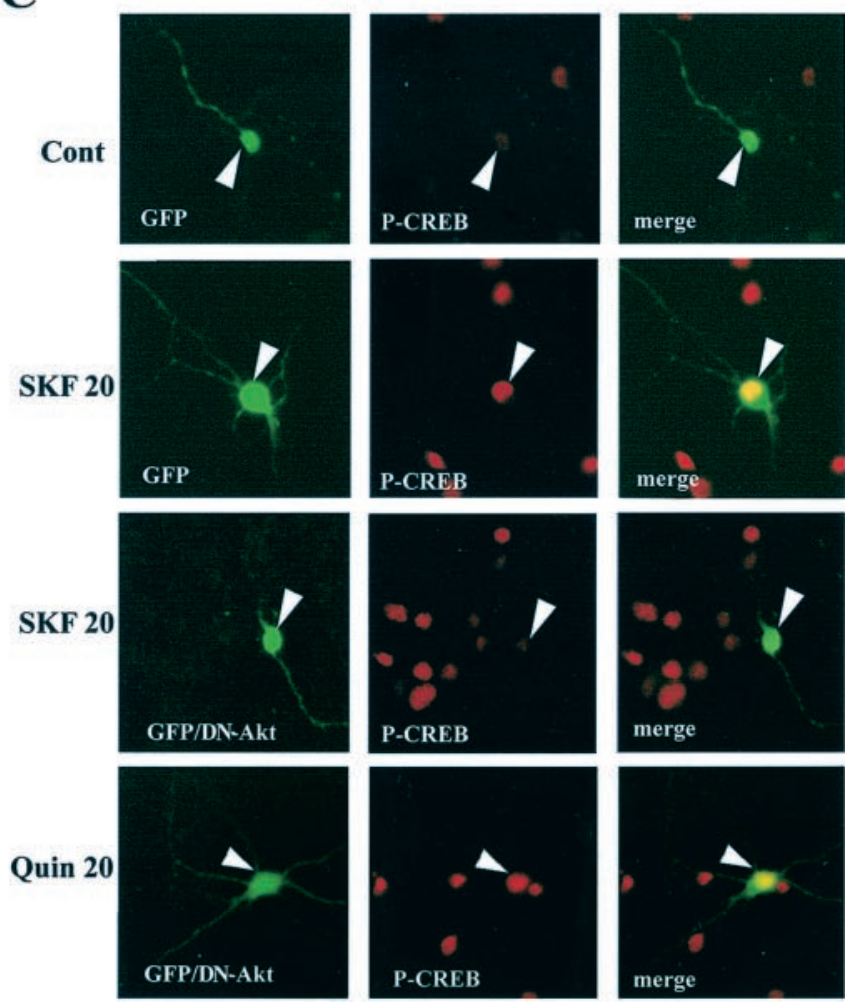

D

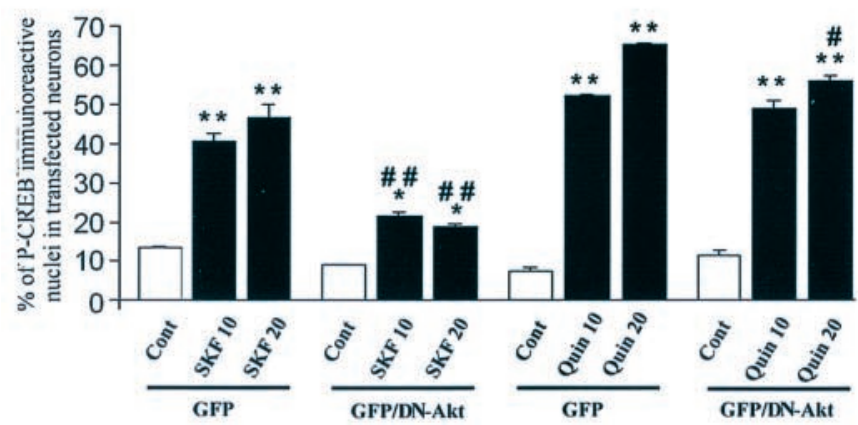

Figure 6. Activated Akt controls CREB phosphorylation induced by D1 agonist treatment. $A$, Striatal neurons were treated for 20 min with SKF, quinpirole, and IGF as indicated. Akt was immunoprecipitated from neuronal lysates using an antibody corresponding to the PH domain, and scriptional rate of anti-apoptotic genes such as Bcl-2 (Riccio et al., 1999), genes involved in synaptic plasticity, including c-fos (Ginty, 1997) or BDNF (Shieh and Ghosh, 1999), as well as precursors of neurotransmitters implicated in drug addiction, such as dynorphin (Carlezon et al., 1998), CREB is a key mediator of long-term phenotypic changes in neurons.

CREB phosphorylation can be induced in striatal neurons, during D1 and D2 receptor stimulation, via distinct pathways. Thus, in striatal slices or primary striatal cultures, D1 receptormediated CREB phosphorylation is highly dependant on PKA (Das et al., 1997) but also, albeit partly, on the ERK pathway (Zanassi et al., 2001). Our data showing that overexpression of DN-Akt impairs P-CREB immunolabeling strongly support the possibility that Akt is also involved in CREB phosphorylation during D1 receptor stimulation. Thus, CREB is a common target to multiple kinases activated by D1 receptors: PKA and Akt, which directly phosphorylate Ser $^{133}$-CREB, and ERK via Rsk and/or MSK.

It was shown recently that D2 receptor-induced CREB phosphorylation requires activation of PKC and CaMK, but not ERK (Yan et al., 1999). We show here that overexpression of DN-Akt failed to affect CREB phosphorylation after $10 \mathrm{~min}$ of D2 agonist treatment. However, a slight but significant reduction was found after $20 \mathrm{~min}$, thus implicating, at least partly, Akt in CREB phosphorylation at this time point. An important observation here is that during D2 receptor stimulation, the number of P-CREB-immunoreactive nuclei was higher (60\%) than P-ERK and P-T-Akt (25\%). From these results we can conclude that activated ERK, and thereby Akt, controls CREB phosphorylation only in a subpopulation of striatal neurons expressing D2 receptors. This might explain why, from global Western blot analysis, Yan et al. (1999) failed to detect any effect of ERK signaling in D2-induced CREB phosphorylation. It could be interesting now to analyze whether the ERK/Akt/CREB module is similarly regulated by D2 agonists in striatopallidal neurons, which mainly express D2 receptors (i.e., $\sim 50 \%$ of medium spiny neurons) (Bloch and Le Moine, 1994), and in striatonigral neurons, which mainly express D1 but also a significant level of D2 receptors (Aizman et al., 2000). This could provide a new basis for further understanding how synergistic actions of D1 and D2 can occur in striatal neurons.

its kinase activity was determined with GST-CREB ${ }_{1-166}$ as a substrate. After washing to eliminate unincorporated radioactivity, samples were subjected to $10 \%$ SDS-PAGE (data are representative of 3 independent experiments). $B$, Immunolocalization of HA-tagged-DN-Akt (DN-Akt) was analyzed with an anti-HA antibody. Note the localization of DN-Akt in both cytosolic (including neuritic extension) and nuclear compartments. Note also the nuclear integrity (Hoechst) of neuronal cells overexpressing DN-Akt. $C$, CREB phosphorylation was analyzed by immunocytochemical detection of the anti-P-CREB antibody. Note that $P$-CREB immunostaining is strongly induced during SKF38393 treatment (SKF 20), including in a GFP-transfected neuron (arrowhead). During SKF (arrowhead) but not quinpirole (Quin 20) (arrowhead) treatment, note the disappearance of P-CREB immunostaining in cells cotransfected with GFP and DN-Akt $(G F P / D N-A k t)$. D, Quantification of P-CREBimmunoreactive neurons was performed from GFP or GFP + DN-Akttransfected neurons in control conditions (Cont), after D1 (SKF 10 and SKF 20) or D2 (Quin 10 and Quin 20) agonist treatments. For each experiment, P-CREB immunostaining was quantified from 100 transfected cells. Data are representative of three independent experiments for each group. ${ }^{*} p<0.05$ and ${ }^{* *} p<0.01$ when compared with the corresponding control group; ${ }^{\#} p<0.05$ and ${ }^{\# \#} p<0.01$ when compared with neurons transfected with GFP alone (Newman-Keuls test). 
Figure 7. In vivo activation of Akt in striatal neurons after cocaine administration. P-T-Akt immunostaining was performed in striatal sections of mice treated with saline or cocaine. P-T-Akt immunoreactivity was increased 10 and $20 \mathrm{~min}$ after cocaine $(20 \mathrm{mg} / \mathrm{kg}$, i.p.) administration (coc 10 and $\operatorname{coc}$ 20 , respectively). Shown is fluorescent confocal analysis of P-T-Akt immunolabeling. Note its nuclear labeling during cocaine treatment ( $\operatorname{coc} 20)$. Data are representative of at least four independent mice for each treatment. saline

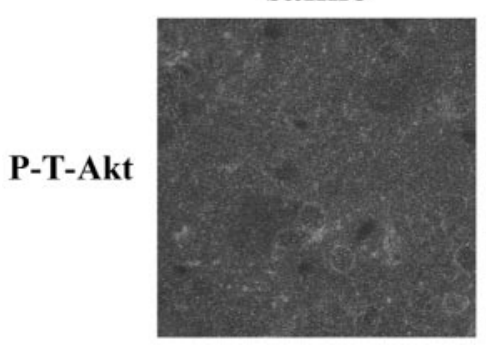

$\operatorname{coc} 10$

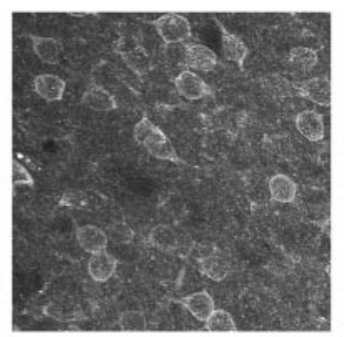

$\operatorname{coc} 20$

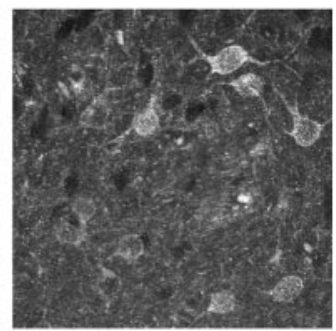

An important finding was that the same activation of Akt occurred in vivo in response to cocaine, a psychotrope drug known to induce long-term neuronal changes in the striatum. Similar kinetics of P-T-Akt immunoreactivity was found when compared with striatal neurons in culture. We note that ERK activation was also found to be activated in the striatum during acute cocaine administration, again with kinetics similar to those found in vitro (Valjent et al., 2000). In this article we clearly showed that ERK activation was involved in both gene regulation and addictive behavior, measured in the place preference test. Thus, further elucidation of the role of Akt in drug addiction is now a critical issue.

To conclude, we propose that Akt participates in a sequential activation of CREB phosphorylation in response to D1 receptor stimulation. Thus, this transduction pathway, along with other several different protein kinases, including PKA and MAPK/ ERK, could convey the prolonged phosphorylation of CREB that is necessary to control gene expression (Wu et al., 2001) and thereby long-term neuronal adaptation in the striatum.

\section{REFERENCES}

Aizman O, Brismar H, Uhlen P, Zettergren E, Levey AI, Forssberg H, Greengard P, Aperia A (2000) Anatomical and physiological evidence for D1 and D2 dopamine receptor colocalization in neostriatal neurons. Nat Neurosci 3:226-230.

Alessi DR, Cohen P (1998) Mechanism of activation and function of protein kinase B. Curr Opin Genet Dev 8:55-62.

Alessi DR, Andjelkovic M, Caudwell B, Cron P, Morrice N, Cohen P, Hemmings BA (1996) Mechanism of activation of protein kinase B by insulin and IGF-1. EMBO J 15:6541-6551.

Alessi DR, James SR, Downes CP, Holmes AB, Gaffney PR, Reese CB, Cohen P (1997) Characterization of a 3-phosphoinositide-dependent protein kinase which phosphorylates and activates protein kinase Balpha. Curr Biol 7:261-269.

Andjelkovic M, Alessi DR, Meier R, Fernandez A, Lamb NJ, Frech M, Cron P, Cohen P, Lucocq JM, Hemmings BA (1997) Role of translocation in the activation and function of protein kinase B. J Biol Chem 272:31515-31524.

Bellacosa A, Testa JR, Staal SP, Tsichlis PN (1991) A retroviral oncogene, akt, encoding a serine-threonine kinase containing an SH2-like region. Science 254:274-277.

Berke JD, Hyman SE (2000) Addiction, dopamine, and the molecular mechanisms of memory. Neuron 25:515-532.

Blendy JA, Maldonado R (1998) Genetic analysis of drug addiction: the role of cAMP response element binding protein. J Mol Med 76:104-110.

Bloch B, Le Moine C (1994) Neostriatal dopamine receptors. Trends Neurosci 17:3-5.

Brunet A, Bonni A, Zigmond MJ, Lin MZ, Juo P, Hu LS, Anderson MJ, Arden KC, Blenis J, Greenberg ME (1999) Akt promotes cell survival by phosphorylating and inhibiting a Forkhead transcription factor. Cell 96:857-868.

Brunet A, Datta SR, Greenberg ME (2001) Transcription-dependent and -independent control of neuronal survival by the PI3K-Akt signaling pathway. Curr Opin Neurobiol 11:297-305.

Burgering BM, Coffer PJ (1995) Protein kinase B (c-Akt) in phosphatidylinositol-3-OH kinase signal transduction. Nature 376:599-602.

Carlezon Jr WA, Thome J, Olson VG, Lane-Ladd SB, Brodkin ES, Hiroi N, Duman RS, Neve RL, Nestler EJ (1998) Regulation of cocaine reward by CREB. Science 282:2272-2275.
Coffer PJ, Woodgett JR (1991) Molecular cloning and characterisation of a novel putative protein-serine kinase related to the cAMPdependent and protein kinase C families. Eur J Biochem 201:475-481.

Das S, Grunert M, Williams L, Vincent SR (1997) NMDA and D1 receptors regulate the phosphorylation of CREB and the induction of c-fos in striatal neurons in primary culture. Synapse 25:227-233.

Datta SR, Brunet A, Greenberg ME (1999) Cellular survival: a play in three Akts. Genes Dev 13:2905-2927.

Davies SP, Reddy H, Caivano M, Cohen P (2000) Specificity and mechanism of action of some commonly used protein kinase inhibitors. Biochem J 351:95-105.

Deak M, Clifton AD, Lucocq LM, Alessi DR (1998) Mitogen- and stress-activated protein kinase-1 (MSK1) is directly activated by MAPK and SAPK $2 / \mathrm{p} 38$, and may mediate activation of CREB. EMBO J 17:4426-4441.

Downward J (1998) Mechanisms and consequences of activation of protein kinase B/Akt. Curr Opin Cell Biol 10:262-267.

Du K, Montminy M (1998) CREB is a regulatory target for the protein kinase Akt/PKB. J Biol Chem 273:32377-32379.

Falasca M, Logan SK, Lehto VP, Baccante G, Lemmon MA, Schlessinger J (1998) Activation of phospholipase C gamma by PI 3-kinaseinduced $\mathrm{PH}$ domain-mediated membrane targeting. EMBO J $17: 414-422$.

Favata MF, Horiuchi KY, Manos EJ, Daulerio AJ, Stradley DA, Feeser WS, Van Dyk DE, Pitts WJ, Earl RA, Hobbs F, Copeland RA, Magolda RL, Scherle PA, Trzaskos JM (1998) Identification of a novel inhibitor of mitogen-activated protein kinase kinase. J Biol Chem 273:18623-18632.

Filippa N, Sable CL, Filloux C, Hemmings B, Van Obberghen E (1999) Mechanism of protein kinase B activation by cyclic AMP-dependent protein kinase. Mol Cell Biol 19:4989-5000.

Franke TF, Yang SI, Chan TO, Datta K, Kazlauskas A, Morrison DK, Kaplan DR, Tsichlis PN (1995) The protein kinase encoded by the Akt proto-oncogene is a target of the PDGF-activated phosphatidylinositol 3-kinase. Cell 81:727-736.

Ginty DD (1997) Calcium regulation of gene expression: isn't that spatial? Neuron 18:183-186.

Hawes BE, Luttrell LM, van Biesen T, Lefkowitz RJ (1996) Phosphatidylinositol 3-kinase is an early intermediate in the $\mathrm{G}$ beta gammamediated mitogen-activated protein kinase signaling pathway. J Biol Chem 271:12133-12136.

Hemmings BA (1997) Akt signaling: linking membrane events to life and death decisions. Science 275:628-630.

Jones PF, Jakubowicz T, Pitossi FJ, Maurer F, Hemmings BA (1991) Molecular cloning and identification of a serine/threonine protein kinase of the second-messenger subfamily. Proc Natl Acad Sci USA 88:4171-4175.

Kawasaki H, Springett GM, Mochizuki N, Toki S, Nakaya M, Matsuda M, Housman DE, Graybiel AM (1998) A family of cAMP-binding proteins that directly activate Rap1. Science 282:2275-2279.

Konradi C, Cole RL, Heckers S, Hyman SE (1994) Amphetamine regulates gene expression in rat striatum via transcription factor CREB. J Neurosci 14:5623-5634.

Lopez-Ilasaca M, Crespo P, Pellici PG, Gutkind JS, Wetzker R (1997) Linkage of $G$ protein-coupled receptors to the MAPK signaling pathway through PI 3-kinase gamma. Science 275:394-397.

Luttrell LM, Daaka Y, Lefkowitz RJ (1999) Regulation of tyrosine kinase cascades by G-protein-coupled receptors. Curr Opin Cell Biol 11:177-183.

Mayford M, Kandel ER (1999) Genetic approaches to memory storage. Trends Genet 15:463-470.

Moule SK, Welsh GI, Edgell NJ, Foulstone EJ, Proud CG, Denton RM (1997) Regulation of protein kinase B and glycogen synthase kinase-3 by insulin and beta-adrenergic agonists in rat epididymal fat cells. Activation of protein kinase B by wortmannin-sensitive and -insensitive mechanisms. J Biol Chem 272:7713-7719.

Nomura M, Kaji A, Ma W-Y, Zhong S, Liu G, Bowden GT, Miyamoto K, Dong Z (2001) Mitogen- and stress-activated protein kinase 1 medi- 
ates activation of Akt by ultraviolet B irradiation. J Biol Chem 276:25558-25567.

Pagès G, Brunet A, L'Allemain G, Pouyssegur J (1994) Constitutive mutant and putative regulatory serine phosphorylation site of mammalian MAP kinase kinase (MEK1). EMBO J 13:3003-3010.

Paolillo M, Montecucco A, Zanassi P, Schinelli S (1998) Potentiation of dopamine-induced cAMP formation by group I metabotropic glutamate receptors via protein kinase $\mathrm{C}$ in cultured striatal neurons. Eur J Neurosci 10:1937-1945.

Perkinton MS, Sihra TS, Williams RJ (1999) $\mathrm{Ca}\left({ }^{2+}\right)$-permeable AMPA receptors induce phosphorylation of cAMP response element-binding protein through a phosphatidylinositol 3-kinase-dependent stimulation of the mitogen-activated protein kinase signaling cascade in neurons. J Neurosci 19:5861-5874

Polakiewicz RD, Schieferl SM, Gingras AC, Sonenberg N, Comb MJ (1998) mu-Opioid receptor activates signaling pathways implicated in cell survival and translational control. J Biol Chem 273:23534-23541.

Riccio A, Ahn S, Davenport CM, Blendy JA, Ginty DD (1999) Mediation by a CREB family transcription factor of NGF-dependent survival of sympathetic neurons. Science 286:2358-2361.

Sable CL, Filippa N, Hemmings B, Van Obberghen E (1997) cAMP stimulates protein kinase $\mathrm{B}$ in a Wortmannin-insensitive manner. FEBS Lett 409:253-257.

Shaywitz AJ, Greenberg ME (1999) CREB: a stimulus-induced transcription factor activated by a diverse array of extracellular signals. Annu Rev Biochem 68:821-861.

Shieh PB, Ghosh A (1999) Molecular mechanisms underlying activitydependent regulation of BDNF expression. J Neurobiol 41:127-134.

Stephens L, Smrcka A, Cooke FT, Jackson TR, Sternweis PC, Hawkins PT (1994) A novel phosphoinositide 3 kinase activity in myeloidderived cells is activated by $G$ protein beta gamma subunits. Cell 77:83-93.

Stoof JC, Kebabian JW (1981) Opposing roles for D-1 and D-2 dopa- mine receptors in efflux of cyclic AMP from rat neostriatum. Nature 294:366-368.

Toker A, Cantley LC (1997) Signalling through the lipid products of phosphoinositide-3-OH kinase. Nature 387:673-676.

Valjent E, Corvol JC, Pages C, Besson MJ, Maldonado R, Caboche J (2000) Involvement of the extracellular signal-regulated kinase cascade for cocaine-rewarding properties. J Neurosci 20:8701-8709.

Valjent E, Caboche J, Vanhoutte P (2001) Mitogen-activated protein kinase/extracellular signal-regulated kinase induced gene regulation in brain: a molecular substrate for learning and memory. Mol Neurobiol 23:83-99.

Wu GY, Deisseroth K, Tsien RW (2001) Activity-dependent CREB phosphorylation: convergence of a fast, sensitive calmodulin kinase pathway and a slow, less sensitive mitogen-activated protein kinase pathway. Proc Natl Acad Sci USA 98:2808-2813.

Yan Z, Feng J, Fienberg AA, Greengard P (1999) D(2) dopamine receptors induce mitogen-activated protein kinase and cAMP response element-binding protein phosphorylation in neurons. Proc Natl Acad Sci USA 96:11607-11612.

Yano S, Tokumitsu H, Soderling TR (1998) Calcium promotes cell survival through CaM-K kinase activation of the protein-kinase-B pathway. Nature 396:584-587.

Yao H, York RD, Misra-Press A, Carr DW, Stork PJ (1998) The cyclic adenosine monophosphate-dependent protein kinase (PKA) is required for the sustained activation of mitogen-activated kinases and gene expression by nerve growth factor. J Biol Chem 273:8240-8247.

York RD, Yao H, Dillon T, Ellig CL, Eckert SP, McCleskey EW, Stork PJ (1998) Rap1 mediates sustained MAP kinase activation induced by nerve growth factor. Nature 392:622-626.

Zanassi P, Paolillo M, Feliciello A, Avvedimento EV, Gallo V, Schinelli S (2001) cAMP-dependent protein kinase induces cAMP-response element-binding protein phosphorylation via an intracellular calcium release/ERK-dependent pathway in striatal neurons. J Biol Chem 276: $11487-11495$ 